\title{
REFIGURING ODYSSEUS’ APOLOGUE IN PLATO'S PROTAGORAS
}

\author{
Àngel PASCUAL-MARTÍN
}

The common $4^{\text {th }}$ century B.C. view according to which Homer was regarded as a poet and a wise man, the leading and most honorable, to the point of being considered "the educator of Greece" (Pl. Resp. 606e-607a), is strongly supported by the Platonic dialogues. The works of Plato are the main available source to get to know not only the great pedagogical esteem for Homer, but also the several educational traditions that used or relied on Homeric poetry in Classical Athens. We are certainly used to thinking of Socrates as standing out for contesting or blaming such customs and methods provided by rhapsodes, sophists and common people (Pl. Resp.; Ion; Hp. mi.). But conversely, he is also often depicted quoting, alluding to or remaking on Homeric passages when presenting his own views. Socrates even claims to feel a certain friendship or reverence for the poet and declares to be charmed by contemplating things through him, whom he considers to be amongst the few deserving to be called "philosophers" (Pl. Resp. 595b; 607c-d; Phdr. 278b-279b).

The puzzling twofold nature of the Socratic attitude towards Homer, coupled with the fact that Plato would become a figure as honored as the poet was, led ancient literary criticism to focus on the Platonic use and sharing of material and techniques proper to Homeric poetry. Works like those of Dionysius of Halicarnassus, Maximus of Tyre, Longinus and above all Proclus, not only pointed out the philosopher's debt to the poet, but even considered him to be an admirer of the Homeric genius unlike anyone else, and whose emulation basically attempted to reach and outperform the pedagogical power that the legendary poet had (Dion. Hal. Pomp. I, 13; Max. Tyr. Or. 26; [Longinus]; Subl. XIII, 2-3; Procl., In R. VI, 163.13-164.7; 202.7-205.23).

HYPOTHEKAI

2021. Вып. 5. С. 43-63

УДК 37.01
HYPOTHEKAI

2021. Issue 5. P. 43-63

DOI: $10.32880 / 2587-7127-2021-5-5-43-63$ 
With an analogous spirit, studies of contemporary Platonists suggest that the dialogues were shaped using the Homeric text, especially the Odyssey, as a template, and making Socrates appear as going through equivalent experiences to those of Odysseus'

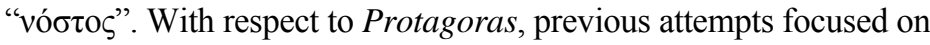
explicit references to books X and XI, placing the dispute with the sophist and the events at Callias' house in the symbolic context of Odysseus' encounter with Circe and the following journey into the underworld. I attempt to bring that reading one step further, paying special attention to the narrated character and the dramatic context for the singing of those episodes and the parallel ones in Protagoras.

In first place, I consider the whole dialogue refiguring the episode in the Odyssey that works as a dramatic frame for the singing of Odysseus' past adventures, the arrival at Phaeacia and the reception at Alcinous' court. I regard Odysseus' need to sing the Apologue as a call for hospitality to secure a safe passage home, working as a pattern for Socrates' need of a tale at his own appearance in Athens to fulfill and secure a philosophical education in the city. In second place, I take into consideration the metanarrative dimension of such remaking. Since Socrates' narration comes in response to a

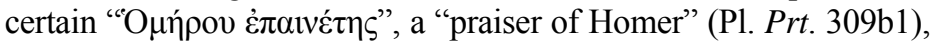

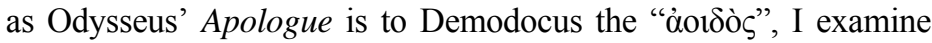
how the dialogue could evince a dispute for pedagogical primacy amongst the different narratives and uses of poetry in Athens, a dispute that the Platonic narrative would attempt to surpass precisely by imitating Homer.

\section{PLATO'S PROTAGORAS AND THE USES OF HOMERIC TEXT AN INTRODUCTORY OVERVIEW}

Apparently, neither poetry in general nor Homeric poems in particular happen to be as decisively included in the main philosophical scope of Plato's Protagoras as they are in Republic, Ion or Hippias Minor ${ }^{1}$. The issue of poetry and its place in education, while certainly discussed in the dialogue, seems rather to have an auxiliary role in the whole inquiry,

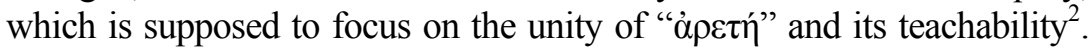

\footnotetext{
${ }^{1}$ See as an example Murray (1996); Destrée, Herrmann (2011).

2 As a token for such a view apropos the interpretation of Simonides' poem (Pl. Prt. 338e-348c) see Adam \& Adam (1893). P. xxiii-xxiv.
} 
However, Protagoras still equals other dialogues not only with its leaving evidence about the place and use of the great poets in Classical Athenian education ${ }^{1}$, and showing the classic Socratic criticism towards such pedagogical practices, but also by making the same Socrates appear as the most expert on poetry, and even as an admirer who cannot help quoting or alluding to literary passages, especially of Homer.

As with many other dialogues, Protagoras reflects the authority Homer was in Greek pedagogical tradition. In particular, Protagoras shows how new trends in education, while moving away from the old paideia and being seen by many as a threat to it, also presented the poet as a sort of ancestor. This is the case of the master from Abdera, who introduces his art of educating as already undertaken by certain ancient sages, who disguised it in other technical skills, such as poetry in the case of Homer (P1. Prt. 316c-317b) ${ }^{2}$. Besides that, Protagoras also presents evidence about the existence of certain pedagogical practices relying on poetry in general, but especially on Homeric poems. The first testimony that the dialogue provides concerns primary education, and it is complementary to the notices from other dialogues, where it is said that the tales of Homer played a critical role in early children's upbringing (Pl. Resp. 377a-d). According to the Great Speech, once children were literate enough, under the tutelage of teachers of letters, the rearing of the young concentrated in reading and learning "the good poets" by heart, for these were supposed to provide them with examples worthy of admiration and imitation (P1. Prt. 325d-326a; Leg. 809-811a; cf. Xenophon, Symp. III, 5). A second testimony comes by indirect allusion too, this time with the interpretation of Simonides' poem (Pl. Prt. 338e348c). Protagoras introduces the examination of the poem stating that to be skilled in verses plays an important part in a man's education, and that such skill would require to be able to go through what they say, and

${ }^{1}$ Plato's dialogues are the main source available to get to know about the pedagogical esteem for Homer and the several educational traditions that used or relied on Homeric poetry in Classical Athens, Robb (1994). P. 160; Verdenius (1970). P. 7-18.

${ }^{2}$ In Plato's Theaetetus, Socrates also takes Protagoras as a follower of Homer and Heraclitus and understands the doctrine "that man is the measure of all things" in complete identity with the doctrine "that all things are in motion, like streams" (Pl. Tht. 160d-e; 152c-153a). 
if they do rightly or not, as well as to know how to distinguish them and account for them when asked (P1. Prt. 338e-339a). As other dialogues show, after the old tradition of rhapsodes, the sophistic movement also engaged in epic and lyric poetry, providing interpretations as well as technical teachings concerning linguistic observations, definitions and classifications (i.e., Pl. Hp. mi. 363a-c; 366a ff) ${ }^{1}$. But the reference to such practice in the words of Protagoras is still more relevant, since above all sophists, the master from Abdera was the most celebrated for having inaugurated and advanced a certain art of criticizing and correcting wording in poetry, especially in Homer (Pl. Cra. 391c; Phdr. 267c; Arist. Poet. XIX. 1456b15; Soph. El. 173b19)².

As we might expect though, in Protagoras, Socrates comes to repudiate such habit of using verses in serious conversations. As he will conclude, to discuss poetry or make arguments by use of it would be childish nonsense proper to unlearned people unable to express their own arguments and incapable of defending them by their own words (Pl. Prt. 347b-348a). However, the explicit philosophical reluctance to use poetry on the part of Socrates contrasts significantly with his own performance in the dialogue. On the one hand, the passage on Simonides will reveal that, more than any other sophist, Socrates himself is the most learned and skilled of all in poetry (Pl. Prt. 338e-347b) $)^{3}$. On the other, the entire course of his narration also shows that he has great sensitivity for poetry, to the point of recurrently relying on epic formulas, adapting expressions or literally quoting celebrated passages especially of Homer.

In the course of the dialogue, Socrates' words seem to reproduce in one way or another different passages from the Iliad or the Odyssey up to six times ${ }^{4}$ :

1) As soon as the dialogue breaks, addressing an unknown com-

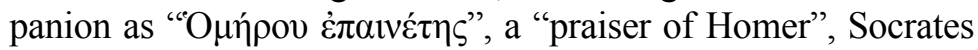

${ }^{1}$ Pfeiffer (1968). P. 16.

2 Ibid. P. 33-39; Rademaker (2013); Woodruff (2017).

${ }^{3}$ Socrates' interpretation of Simonides is usually considered a satirical attempt on his part (or a parody, on Plato's) to demonstrate how ridiculous the sophistic method could get commenting the poets. See Adam \& Adam (1893). P. xxiii-xxv; Guthrie (1975). P. 227.

${ }^{4}$ Labarbe only considers five of them, not including (2) in our list: Labarbe (1949). P. 213-214; 214-217; 260-262; 309. 
reminds him apropos Alcibiades that, according to the poet, the one "getting his first beard" happens to be in the age of "the fairest youthful prime" (Pl. Prt. 309b1), in reference to the graces of Hermes (Hom. Od. X.279; Il. XXIV.348).

2) Shortly after, the Socratic narration makes Hippocrates utter a Homeric formula when he explains why he came in the early morning. Only learning late at night that Protagoras was in town, he went to sleep, but woke up and set off for Socrates' as soon as the "sleep freed" him from tiredness (Pl. Prt. 310d1) (Hom. Od. VII.289; XVIII.199; XIX.551; XXIV.440; Il. II.71). The two following quotes appear connected in the same context, that is, the Socratic description of the spectacle witnessed at Callias' house as he and Hippocrates entered it (Pl. Prt. 314e4-316a5).

3) Having first fixed his attention on Protagoras and the choir of his followers, Socrates says, as Homer makes Odysseus tell, that "after him" he "could see" Hippias of Elis (Pl. Prt. 315b9 = Hom. Od. X.572; XI.601).

4) In addition, after describing how Hippias is lecturing, Socrates will announce the presence of Prodicus, also employing an expression belonging to Odysseus' journey to the underworld: "I also saw Tantalus" (Pl. Prt. 315c9= Hom. Od. XI.583).

5) Further on, in the context of the exegesis of Simonides' poem, Socrates demands Prodicus' assistance to stop Protagoras' attacks. There, Socrates pretends to be Scamander calling Simois to stop Achilles when the latter entered the river to escape from the Trojans, as the gods got also involved in battle: "Dear brother, let us both contain the man's strength!" (Pl. Prt. 340a4$5=$ Hom. Il. XXI.308-309) ${ }^{1}$

6) Finally, after the interpretation of Simonides, as Protagoras is unwilling to continue with the inquiry, Socrates tells him that he has no other intention than to elucidate some issues, and that no one but the sophist could be more helpful with that purpose. And reproducing the words of Diomedes asking Nestor for someone to escort him to the Trojan's camp (Hom. Il. X.224225) he adds: "[when] two are going together, one understands

${ }^{1}$ See Capra (2005). 
first", "but if a lone man understands" he should go searching somebody to show it off and corroborate it (P1. Prt. 348d1-3; cf. Symp. 174d2-3; [Alc. Mi.] 140a1-2) ${ }^{1}$.

The uses of the Homeric text in the dialogue seem to contribute in large extent to a more accessible and enjoyable picture of the meeting and the philosophical exchange that Socrates had with the great sophist from Abdera. Accordingly, the feature is without doubt essential to the impression that Protagoras is, together with Symposium, Phaedo or Republic, one of the most beautifully created Platonic dialogues ${ }^{2}$. However, according to a great majority of scholars, neither the feature of using Homer nor the whole poetic masterpiece resulting from it seem to have enough relevance for the philosophical outcome of a dialogue which, in terms of arguments, is still considered to be preparatory, at best ${ }^{3}$.

\section{REFIGURING ODYSSEUS' APOLOGUE I A NEWLY ARRIVED EDUCATOR CALLING FOR HOSPITALITY}

At the moment, Heda Segvic's is the most comprehensive study about the meaning of Homeric allusions in Protagoras ${ }^{4}$. According to her, the Homeric references in the dialogue would not work simply as an artistic adornment that has barely any influence in the philosophical outcome; on the contrary, she sees some of these allusions as helping significantly to erect the symbolic web where the arguments are set ${ }^{5}$. Segvic's reading of Protagoras mainly focuses on the reference in the opening alluding to Hermes' graces (1) and the couple of quotations at the entry of Callias' house mentioning the souls' sighting in Hades (3) (4). She locates the first one in book X of the Odyssey ${ }^{6}$, which is when

${ }^{1}$ See Proscurcin (2018); Rosen (1968). P. 24.

${ }^{2}$ Segvic (2006). P. 247.

${ }^{3}$ See Adam \& Adam (1893); Wilamowitz-Moellendorf (1920); Bodin, Croiset (1923); Guthrie (1975). Cf. Jaeger (1933-1947); Reale (2001).

${ }^{4}$ Segvic (2006); cf. Johnson (1992).

${ }^{5}$ Segvic (2006). P. 247-248.

${ }^{6}$ There is a verse of the Iliad (Hom. Il. XXIV.348) identical to the one quoted in Protagoras, where Hermes appears in the same youthful shape. There he comes in help of Priam on his way to the ships of the Achaeans in an attempt to recover the corpse of Hector. 
Circe has beguiled and turned Odysseus' companions into boars (Hom. Od. X.210-243) and the hero is going in search of them (Hom. Od. X.273). It is then that Hermes appears as the one "getting his first beard, in the fairest youthful prime" (Hom. Od. X.279; Pl. Prot. 309b1). He provides Odysseus with an herb to counteract Circe's powers and instructs the hero how to manage her (Hom. Od. X.286-301). The son of Laertes will thus avoid the sorcerer's spell and thwart her further actions (Hom. Od. X.310-347). At the end of the book, a year after that episode, Circe will let Odysseus leave as promised, telling him to meet with Tiresias in the underworld (Hom. Od. X.488-495). What follows in book XI is his encounter with the foreseer and many other souls in Hades, amongst the last of them, Tantalus (Hom. Od. XI.583) and Heracles (Hom. Od. XI.601). To them are addressed the words also employed in Protagoras (Pl. Prt. 315b9; 315c9) ${ }^{1}$.

Relying on these references, Segvic claims that, in Protagoras, Plato placed the dispute between Socrates and the sophist at Callias' house in a reimagining of the encounter with Circe and the following journey into the underworld. The call to Hermes' graces apropos Alcibiades -the actual assistant of Socrates in the dialogue (Plat. Prt. 309b5; cf. 334c-338e; 347b3-7; 348b2-8) is to announce the dangers faced earlier in the day. It would indicate that Socrates required supernatural protection, help and guidance to evade and counteract the enchantment and poisoning resulting from the speech powers of a sophist, Protagoras, who would parallel Circe and who is actually likened to Orpheus (Plat. Prt. 315b1) $)^{2}$. Socrates' encounter with the sophist would thus be presented as a mission in rescue of a group of friends, who would have experienced or risk to experience a dangerous transformation at the hands of Protagoras the sorcerer and the other sophists' teachings ${ }^{3}$.

According to Zdravko Planinc, who has made major contributions on Plato's use of the Odyssey as a source text, studies like Segvic's may

${ }^{1}$ Reference (3) in Pl. Prt. 315b9 equals the formula at the same time used for the sight of Orion (Hom. Od. X.572) and Heracles (Hom. Od. XI.601). Segvic (2006). P. 256 considers that it is much likelier that the reference is to the latter. Cf. Adam \& Adam (1893). P. 100.

${ }^{2}$ For the sophist as a magician or a sorcerer see Pl. Soph. 234c5; 235a1; $235 \mathrm{a} 9 ; 241 \mathrm{~b} 6$.

${ }^{3}$ Cf. Capra (2001). P. 131-135, 138. 
still be too narrow. Planinc claims that, beyond direct textual references, greater attention must be paid to literary form, structure and action in the Odyssey as a guide for reading the dialogues. In his view, the literary tropes of Odysseus' wandering and homecoming would be consistently refigured by Plato's imitating equivalent experiences in the storyline of Socrates' life. The overarching narrative traced in the dialogues would thus present a process of spiritual transformation analogous to Odysseus', but of a new Greek hero portrayed in the figure of the philosopher. During such process Socrates would find himself following several critical experiences that not only make him emerge as what he is, but also make him capable of doing good to other individuals and to the political communities hosting him ${ }^{1}$.

The Odyssey's episodes quoted in Protagoras and used in Segvic's reading, altogether with the other adventures from books IX to XII, belong to Odysseus' Apologue. Within the entire Odyssey, which is recounted by an external primary narrator, Homer makes the complete tale of Odysseus' adventures beginning when he and his comrades left Troy to be secondarily reported by the same hero in the first-person in the course of the action, his "vó $\sigma \tau \varsigma \varsigma$ ". In Protagoras, the happening at Callias' house that refigures those episodes of books X and XI of the Odyssey also belongs to a "secondary" internal narration recounted by Socrates in the first-person in the course of the philosophers' everyday life in Athens ${ }^{2}$. For this reason, we wonder if Protagoras may not only refigure the events reported, but also the dramatic setting for the singing of the son of Laertes, that is, the arrival at Scheria and his reception at the court of Alcinous, king of Phaeacians ${ }^{3}$.

${ }^{1}$ Planinc (2003). P. 1-24; Planinc (2007). Cf. Lampert (2010). The latter claims that the Platonic corpus shows the temporal development of Socrates thought.

${ }^{2}$ It must be said that in Protagoras properly there is no such a thing as a primary external narration. However, I consider the internal narration "secondary" in relation to the dramatic action that leads to it. It is also significant that both texts follow a circular pattern of composition: the frame scene where the "singing" is set happens to be the episode that comes after the end of the story reported.

${ }^{3}$ Cf. Planinc (2003) who considers that the arrival at Scheria and the reception at the court of Alcinous are refigured in Timaeus and Critias. 
In book V of the Odyssey, Odysseus is released from Calypso and allowed to continue his journey back to Ithaca. On the way, however, he must stop at Phaeacia. Phaeacians are supposed to help and speed his long-awaited return, as this is what Zeus decrees (Hom. Od. V.34-37) and what Alcinous grants later on (Hom. Od. VII.191-194; VII.315-319; VIII.31). But the stay at Scheria could make Odysseus feel that the homecoming might be delayed or even endangered once again. It is not just that a ship must be built first and a party held to entertain and honor the stranger as the custom mandates (Hom. Od. VIII.34-56). It is also, as Odysseus is first warned by Nausicaa and Athena (Hom. Od. VI.274; VII.32-33) and later comes to experience in his own flesh through the insolence and aggressiveness of Phaeacian youths (Hom. Od. VIII.132$255)$, that the locals might not be as friendly as they seemed ${ }^{1}$. Besides that, the plans that Alcinous has for the hero to marry Nausicaa (Hom. Od. VII.311-315) could compromise Odysseus' return too ${ }^{2}$. Finally, Odysseus will be forced to postpone his departure, narrating at large his own adventures (Hom. Od. IX-XII) when he cannot escape to answer Alcinous about his identity and origin (Hom. Od. VIII.550-564) ${ }^{3}$. In the background of the action of the epic poem, Odysseus' Apologue has been considered a call for hospitality, essential to ensure a successful return to Ithaca ${ }^{4}$. The tale of Odysseus about his own past adventures has been read as a stratagem in his attempt to gain the necessary trust and favor from the hosts. That is, apart from delighting the audience as the most celebrated of singers would do (Hom. Od. XI.334; 367-369),

${ }^{1}$ Benardete (2008). P. 45-61.

${ }^{2}$ De Jong (2004). P. 19-22; Miralles (2005) P. 121-122. De Jong (2001). P. 212 considers that Nausicaa figuring as a helper becomes also a danger herself. It makes sense since, in order to become a helper of Odysseus, Athena suggested her that is time for her to get married (Hom. Od. VI.26-28) and a marriage could ruin Odysseus homecoming.

${ }^{3}$ Before that, Odysseus concealed for a long time his identity (Hom. Od. VI-VIII) and he demands to listen more of Demodocus' songs (Hom. Od. VIII.487-498).

${ }^{4}$ The Apologue has also been considered a cathartic exercise of selfrecognition, through memory and reconstruction of his earlier experiences. This way Odysseus will bolster his confidence with regard to his arrival home. See De Jong (2001). P. 195-196; 221; Tracy (1997). P. 366. 
by telling his marvelous misfortunes and portraying the bad hospitality he suffered in other domains, he would be instructing the current hosts about the rules of hospitality to be observed towards the stranger ${ }^{1}$.

In turn, Plato's Protagoras represents Socrates' first public appearance in Athens. The dialogue is set around 433 B.C. ${ }^{2}$. No other dialogue is dramatically set before that date. In fact, in the Platonic dialogues there are memories of a younger Socrates, but these memories portray him as apolitical, that is, as a philosopher whose scope is only physical or metaphysical, and whose public activity and role are nonexistent ${ }^{3}$. Accordingly, like Odysseus' arrival at Scheria and his presentation before the Phaeacians, Socrates' appearance before a group of Athenians at the opening of Protagoras (Pl. Prt. 309a-310a) represents the experience of the solitary hero when he first contacts a political community. This is, in a broader sense, the experience of the stranger arriving at a new domain which is still unknown and uncertain. In a specific sense, concerning only Socrates as a thinker, this is the experience of philosophy becoming political ${ }^{4}$.

In addition to the dramatical chronology, the fact that Protagoras makes an issue of the philosopher's appearance at the city is plainly reflected in the first words of the dialogue. The dialogue breaks with an unknown character reacting with surprise to the unexpected presence of

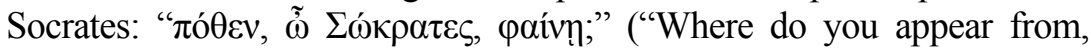
Socrates?", Pl. Prt. 309a1). The use of " $\pi$ ó $\theta \varepsilon v "$ recalls the common epic formula repeatedly addressed to Odysseus to demand for his identity and background when he arrives at a new domain or remains unknown by the

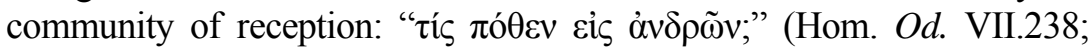
X.302; XIV.190; XIX.105; XXIV.297; cf. Il. XXI.150) $)^{5}$. On the other

${ }^{1}$ Most (1989); Broeniman (1996). P. 10.

2 Adam \& Adam (1893); Morrisson (1941) Nails (2002); Lampert (2010).

${ }^{3}$ For the narrative character of those memories in contrast with the dramatic appearances, and the apolitical nature of Socrates in those memories, see: Lampert (2010); Zuckert (2009).

${ }^{4}$ Lampert (2010). P. 9-10.

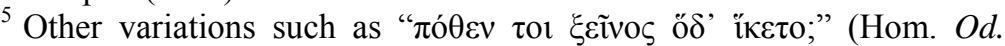
XVI.57) are even closer to the one in Protagoras. See other uses of " $\pi$ ó $\theta \varepsilon v "$ connected with the meeting with strangers in Hom. Od. III.71; IX.252; XV.423. Regarding the use of " $\pi$ ó $\theta \varepsilon v "$ in Pl. Prt. 309a1, see Pascual (2016). 


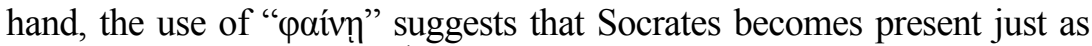
an apparition, a phantom ${ }^{1}$, more or less as Odysseus does when he reaches Alcinous' palace escorted and assisted by Athena, and surprisingly appears suddenly at Arete's knees (Hom. Od. VII.139-145). In such circumstances, as the son of Laertes is first asked by Arete (Hom. Od. VII.238), and as it is later extendedly demanded by the same Alcinous in what gives way to the hero's Apologue (Hom. Od. VIII.550-564), the unknown character who addresses Socrates with these words in the opening of Protagoras is also asking for the origin, the motivation or the circumstances that made such an otherworldly creature appear in town ${ }^{2}$.

When Socrates first appears, the Athenians already have the impression that he does appear from hounding around the youthful prime of Alcibiades, but they attempt to know more about it (Pl. Prt. 309a1-2). It is not simple curiosity or interest that motivates that inquiry, though. Alcibiades is one of the greatest hopes of Athens, and the townspeople have some hesitations in regard to the intentions that the newly arrived may have when he approaches him. Or even more. Just as the Phaeacians would distrust seeing a stranger with Nausicaa (Hom. Od. VI.276-288) and, if they do, they may become hostile to him (Hom. Od. VII.32-33), the townspeople of Athens immediately show some distrust of Socrates being around the son of Kleinias, a distrust with which a menace is also made implicit. Courting Alcibiades when he has already grown a beard, might something against the traditional mores of the city (P1. Prt. 309a2-4; cf. Pl. Symp. 181d-e.) $)^{3}$. For Socrates and whatever he is attempting to do with the youth turns to be questionable, if not under threat if one considers the philosopher's real destiny in Athens (Pl. Ap. 24b; 33a-b; Xen. Mem. I.2.12-16). At his arrival, the major purpose Socrates may have in the city in practical or political terms -that is, a sort of philosophical edu-

P. 134-141; cf. Denyer (2005). P. 65; Lampert (2010). P. 21-22; Cf. Altman (2020). P. 59.

${ }^{1}$ Strauss (1965). IV. P. 4.

${ }^{2}$ It must be added that Socrates, as Odysseus did, doesn't answer immediately to the question about his origin, but he postpones it until he has some certainty that initial suspicions or accusations are more or less deluded (Pl. Prt. 309b-d).

${ }^{3}$ According to him, the beard indicates that it is not appropriate to treat

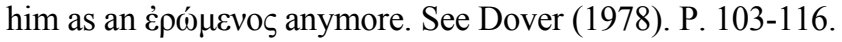


cation of the best local youth- seems to be at least as endangered as Odysseus' return could be with his stopover at Scheria.

Given that the reaction from the townspeople of Athens before Socrates' appearance at the opening of the dialogue is what will give way by action and argument to the Socratic report about his recent adventures on his journey at Callias' house, I maintain that this reported dialogue must be read as Odysseus' Apologue before the Phaeacians that is to say, whether true or false ${ }^{1}$, as the stranger's great stratagem to avoid distrust and potential hostilities and to gain the necessary trust and favor from the hosts to secure his mission. In other words, I claim that the narration in Protagoras must be read as the necessary ploy that Socrates is provided with to create a new appearance for philosophy, one that avoids the disruptive appearance at his arrival, one that generates enough confidence in townspeople to let him have a space and carry out his mission of educating the youth in all that philosophy manages to accomplish in the great city of Athens. It makes complete sense that he might get it narrating a story that presents how he would behave and with such intentions when the youth of Athens approach him in search of educational advice, as he did with the young Hippocrates (Pl. Prt. 310a-314c). It also makes sense that he narrates how he would argue and defeat Protagoras, whose reputation for wisdom and for contributing to the welfare of the city is without doubt, while elucidating how philosophy could help citizens to become excellent (P1. Prt. 314e-362a). With a narration as such, a young Socrates could accomplish not only paving the way for philosophy in the city as an activity concerning the youth, but could even win a reputation for himself as the greatest Greek educator of his time ${ }^{2}$.

${ }^{1}$ If the Socratic narration in Protagoras follows the pattern of Odysseus' Apologue, it must be taken as possible that the reported adventures are not entirely true. Almost every time the son of Laertes appears as a stranger, he delivers a narrative which, if not always is a lie, never fits reality. Considering just the Apologue, Parry (1930) states that it is completely false, and Most (1989) notes that the story is presented in an apparent veracity that is anomalous. Cf. De Jong (2004).

${ }^{2}$ Cf. Lampert (2010). P. 9. 


\section{REFIGURING ODYSSEUS' APOLOGUE II NARRATIVES IN CONTEST FOR PEDAGOGICAL PRIMACY}

In addition to the function that the Apologue plays in the storyline of Odysseus" "vó $\sigma \tau \varsigma \varsigma$ ", the setting for the tale of the adventures of the hero in the epic poem also entails a metanarrative dimension. In the Odyssey, the singers' performance is recurrently employed by Homer to reflect his own consciousness and awareness as a narrator, and by extension, about the nature, practice and reception of narrative in general ${ }^{1}$. Partly detaching the singers' performance from the current actions that come to be narrated, Homer would show how singers relate with events, how these events are received and presented, what intentions the bards have in reciting, how they relate with listeners in different circumstances or what kind of effect they expect to cause in those. The Homeric poems repeatedly depict bards reciting the words of the muses and audiences listening to singers. But this feature seems to be accentuated in the dramatic setting of Homer's fullest account of bardic performance, as in Odysseus' Apologue in Alcinous palace, not only because it comes to contrast two different narratives about the hero, but also because one of them comes from a professional singer and the other one from the main character of the story.

Odysseus' Apologue comes in response to the songs that Demodocus recited earlier to entertain the stranger and the rest of the audience (Hom. Od. VIII. 73-82; 266-366; 499-520). Demodocus figures as a

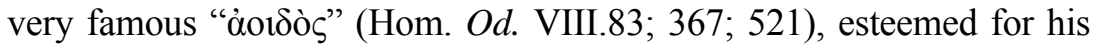
words and stories (Hom. Od. VIII.62; 471) to the point of being considered a divine figure (Hom. Od. XIII.27). His songs, especially those dedicated to Odysseus, have made the hero break down in tears (Hom. Od. VIII.83-92; 521-534). Odysseus is so moved by Demodocus' words that he praises the bard for his beautiful reciting (Hom. Od. VIII.477481; 487-498). However, Demodocus' songs may not be entirely accurate $^{2}$. In a sense, Odysseus' Apologue comes to rival the songs of Demodocus about the Trojan war, and more specifically how the hero is to be depicted in them. At the end, even the local audience has the impres-

${ }^{1}$ De Jong (2001). P. 192; Segal (1994). P. 113-183.

${ }^{2}$ Broeniman (1996). P. 6; 8-9 considers that Demodocus' first song (Hom. Od. VIII. 73-82) is a distorted Iliad. 
sion that no other person could sing better than Odysseus (Hom. Od. XI.335-337; 363-369). Even though he is not a singer technically speaking $^{1}$, he knows better than any other singer his own story, and no other singer can sing better his own glory either.

The frame dialogue of Protagoras depicts an analogous scene in terms of structure. The narration of Socrates about his meeting with the

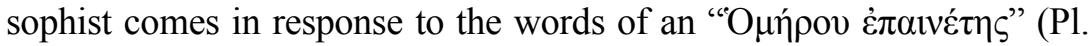
Prt. 309a5). The unknown character who reacts to the philosopher's appearance at the opening of the dialogue is called by Socrates as exactly the same as Io from Ephesus (P1. Io 536d3; 541e3). The word used

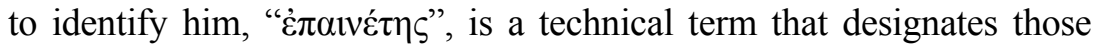
men in Plato's times who, like Demodocus in Homer's, were professionally dedicated to recite tales. They are those experts in poems who not only sing their words, but also know their meaning and interpret them before an audience, i.e., rhapsodes (P1. Io 530b-c) ${ }^{2}$. Besides that, though, "غं $\pi \alpha \mathrm{t} \varepsilon \dot{\varepsilon} \tau \eta$ " also refers to that manner of preciously celebrating the beauty of the poets and their productions, especially Homer's, that is,

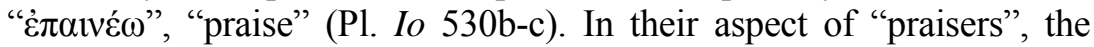
rhapsodes are not supposed to merely transmit the words of the poet,

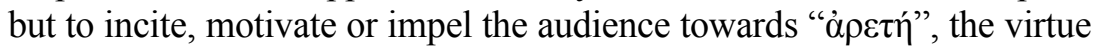
exemplified in them (Arist. Rh. 1367b22; 28). They are supposed to

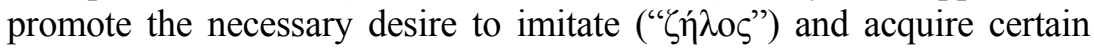
qualities or to emulate certain noble men like Odysseus, Nestor or Achilles $^{3}$. This is the way rhapsodes have become, from Demodocus to Io, rather than mere reciters, conveyors of the proper mores of society, teachers of excellence, and thus pedagogical authorities themselves. In fact, it is due to them that Homer has been considered "the educator of Greece" (Pl. Resp. 606e-607a) .

${ }^{1}$ De Jong (2001). P. 229.

${ }^{2}$ See Liddel, Scott (1996). P. 603-604; Nagy (1979). P. 98. Cf. Velardi (1989). P. 32-33.

${ }^{3}$ That is to be understood in the context of a culture of praise. In that context the nature of the rhapsode's reciting is essentially epideictic, Capuccino (2005). P. 141; 146; 159.

${ }^{4}$ Robb (1994). P. 163; 165; Capuccino (2005). P. 163. We can say they were considered to adults what teachers of letters were to children (Pl. Prt. 325d-326a; cf. Pl. [Hipparch.] 228b-c). 
A character as such is the one demanding for the origin of Socrates (P1. Prt. 309a1), the one taking for granted that the reason for his appearance has to do with Alcibiades (P1. Prt. 309a1-2), the one censuring a hypothetical relationship with the youth (P1. Prt. 309a2-4) and the one whose curiosity and suspicion will be calmed when Socrates tells him about the great meeting our hero had with Protagoras, the wisest man in

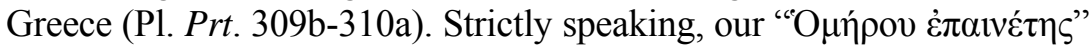
does not appear singing at all in the dialogue, not even the Homeric verses. But he does appear attempting to exhibit his educational authority concerning the moral traditions as well as the epideictic ability to convey this authority when he disapproves of Socrates courting Alcibiades (P1. Prt. 309a2-4) ${ }^{1}$. The "praiser" is certainly using that skill and the educational power that it confers to make of Socrates not the object of admiration, but of rejection. For blame, just as praise, also entails the pedagogical power of example; but rather than of what excels and therefore of what should be admired and imitated, it is the example of what is lowest or shameful, and thus of what should be despised and avoided ${ }^{2}$.

While Homer shows in the Odyssey how Demodocus' singing of certain men's greatness entails a self-referential tendency (Hom. Od. VIII.73-74), Plato pictures the rhapsode's songs, and praise in general, not only as attempting to attract the public towards the beauty of the poet and the great men he praises, but also towards the beauty of his own art of recitation, towards his own beauty as a singer (Pl. Io 530c; cf. Lys 251e $)^{3}$. This is also how the disapproval of Socrates' behavior towards Alcibiades in Protagoras must be read. It is not a strict blame to dissuade others to follow Socrates' example. It is an attempt motivated by envy to break up the educational-erotic attraction that young people might feel towards Socrates, and manage to turn it towards the "praiser" himself. Socrates could be seen at his arrival as an opponent coming to replace, in terms of youth education, the function that the advocates of the Homeric tradition and the old paideia had in Classical Athens. Accordingly, the scene might suggest that the "praiser of Homer" no longer seduces young people enough to entrust him with their education.

${ }^{1}$ See note above: According to him, the beard indicates that it is not appropriate to treat him as an غ̇

${ }^{2}$ See Capuccino (2005). P. 139-140.

${ }^{3}$ Nightingale (1993). 
The "praiser's" open condemnation of Socrates might express the enviable need to redeem himself from his educational incompetence by spreading a certain calumny against the ones taking over his longstanding pedagogical space in society.

In the end, even the "praiser of Homer" may not fully disapprove of the attitude he attributes to Socrates towards young people. In fact, he may not really care or may not even know for sure if Socrates' behavior is reprovable or not. For, when one praises or blames for the sake of reputation as he does, when one's aim in praising or blaming is to please others with words, one may disregard what is actually good and what is bad, beautiful and shameful, or even more, one might simply lie on purpose about it. This is the risk of depravation of a pedagogical culture based on "praise and blame ethics" (Pl. Resp. 363a; 593d; Prt. $313 \mathrm{~d})^{1}$, and this is the way the singers of Homer, the rhapsodes, in their condition as "praisers", could become totally incompetent to educate, if not corruptors themselves.

The manner in which Socrates answers back the disapproval he first received from his companion comes to reflect how the Homeric tradition represented by these rhapsodes was falling in such educational weakening and decay, and what the philosophers had that could save it and make of philosophy a new educational power. As a "praiser of Homer", the unnamed companion should have known that Homer praises the one "getting his first beard" (Pl. Prt. 309b1) but he undervalues Alcibiades on this very basis (P1. Prt. 309a2-4). When he insinuates that the beard appearing on Alcibiades' chin should repel Socrates from approaching him, he should have thought about the great qualities and beauty that could come with that age as it is pointed out by Homer in the passages where Hermes comes in aid of Odysseus (Hom. Od. X.279; Il. XXIV.348). Instead, he seems only to be thinking in the bodily or carnal qualities of Alcibiades, or to be considering these kinds of qualities in relation to real beauty (P1. Prt. 309c1-9). He clearly does not understand Homer, and thus he cannot understand Socrates either. Indeed, Socrates knows better than his companion what Homer says and he is even a better interpreter of his work too. He is a better advocate and conveyer of the highest morals that the Homeric poems convey.

\footnotetext{
${ }^{1}$ Capuccino (2005). P. 162-163.
} 
When he presents himself as a lover of wisdom (P1. Prt. 309c10-d2), he not only seems to agree more with Homer's idea of beauty, but to live according to those morals more truly. However, this is not so merely because Socrates had a better knowledge of Homer, which of course is true, but rather because only he, just as with Odysseus from the moment he received from Hermes a certain knowledge of nature (Hom. Od. X.304-306), would know the essence of what is good and bad, beautiful and shameful ${ }^{1}$. Only with that knowledge can one become a true educator, that is a true conveyor of those morals represented in Homer's poem. After all, this is how Socrates in his first contact with the citizens of Athens would appear as the true "praiser of Homer". This is the only way of singing Homer and his hero properly, or any other story that may resemble Homer's, like Socrates'.

Just as Homer reflects in the Odyssey his own consciousness and awareness concerning the nature, practice and reception of narrative, so does Plato in the dialogues. The whole Platonic Corpus seems to explore the nature and effects of several rivaling approaches and practices in the use of poetry that make the memorial of the great men a pedagogical occasion of first order. As many dialogues show, in Socrates' Athens, competition in narrative was to a large extent a dispute for pedagogical primacy in the city. In Protagoras, the setting and the course of that dispute have a special meaning. At the breaking of the Platonic narrative about the Socratic phenomenon in Athens, the need for a public presentation of philosophy that paves the way for a new educational approach in the city is ironically demanded by the fact that at the opening of the dialogue Socrates comes on stage before a certain "praiser of Homer". Socrates appears in front of someone who is supposed to be an advocate of the old paideia, and who sees in the philosopher's appearance at his arrival a real threat to the traditional mores of the city. However, the Socratic response to such suspicion done as it is in Homeric terms leaves the impression that, rather than a subversion inserted by new unconventional wisdoms, there is in Athens a certain degradation and simplification of the traditional Homeric knowledge by those supposed to be in charge of its preservation and transmission. While a decay as such is represented as the reason why the city already

${ }^{1}$ Strauss (1965). IV. 8; Lampert (2010). P. 23-24. 
suspects and accuses Socrates of corrupting the youth - more than thirty years before his trial —, it also comes on stage as an opportunity for Socrates in the very beginning of his mission to adapt himself and occupy an educational space in the city. In the context of such pedagogical rivalry with the "praiser of Homer", the Socratic refiguring of some of Odyssey's episodes to narrate his recent dispute with Protagoras, expands on the impression that the pedagogical nature and space that philosophy has come to fulfill and occupy in Athens, contrary to what it would seem, would only be possible through some sort of restoration of the traditional wisdom and the musical productions resulting from it, that is, mainly, of epic poetry. It is a restoration of this kind that Socrates seems to need in order to get rid of the bad reputation he already has and thus to create a new appearance that paves the way for philosophy to be welcomed and embraced in the city as a permitted pedagogical power. It is a restoration of this kind that Socrates seems to conduct, on the basis of a certain knowledge of nature, to preserve the true pedagogical power of Homer. Most likely, it is also a restoration of this kind that Plato would attempt to undertake with the dialogues in order to reach a public beyond the walls of the Academy with his philosophy. The art of refiguring Homer certainly seems to be one of the most essential resources that Plato displays in his art of writing in order to reach a pedagogical power comparable to that of the legendary poet. I think is no exaggeration to say that if Plato himself had ever become something akin to an educator of the Greeks, it would have only happened by imitating and refiguring Homer in his writings. Likewise, I think is no exaggeration either to say that with Platonic philosophy, the reading of Homer becomes even more powerful in educational terms.

\section{REFERENCES}

Adam, J., Adam, A.M. (1893) Plato. Protagoras. London: Cambridge University Press.

Altman, W.H.F. (2020) Ascent to the Beautiful: Plato the Teacher and the PreRepublic Dialogues from Protagoras to Symposium. London: Lexington Books.

Bodin, L., Croiset, A. (1923) Platon. Oeuvres Complètes. t. III, 1re partie: Protagoras. Paris: Belles Lettres. 
Bernadete, S. (1997) The Bow and the Lire. Platonic Reading of the Odyssey. Lanham - Boulder - New York - Toronto - Plymouth: Rowman and Littlefield.

Broeniman, C. (1996) "Demodocus, Odysseus and the Torjan War in Odyssey 8", The Classical World 90.1, 3-13.

Capuccino, C. (2005) Filosofi e rapsodi. Testo, traduzione e commento dello Ione platonico. Bologna: CLUEB.

Capra, A. (2001) Agon logon: il Protagora di Platone tra eristica e commedia. Milano: LED.

Capra, A. (2005) "Protagoras' Achilles: Homeric Allusion as a Satirical Weapon (Pl. Prt. 340a)", Classical Philology 100, 274-277.

Johnson, A. (1992) “Allusions to Homer in the Protagoras", Anthós 1.3 (19901996), 55-62.

De Jong, I.J.F. (2001) A narratological commentary on the Odissey. Cambridge - New York: Cambridge University Press.

De Jong, I.J.F. (2004) "Homer", I. J.F. de Jong, R. Nünlist, A. Bowie, eds. Narrators, Narratees and Narratives in Ancient Greek Literature. Studies in Ancient Greek Literature. Vol. I. Leiden: Brill, 13-24.

Denyer N. (2008) Plato. Protagoras. Cambridge: Cambridge University Press.

Destrée, P., Herrmann, F.-G., eds. (2011) Plato and the Poets. Leiden: Brill.

Dover, K.J. (1978) Greek homosexuality. Cambridge: Harvard University Press.

Guthrie, W.K.G. (1975) A history of Greek philosophy. IV. Plato, the man and his dialogues: earlier period. Cambridge: Cambridge University Press.

Jaeger, W. (1933-1947) Paideia. Der Formung des griechischen Menschen, 3 vols. Berlin: Walter de Gruyter Verlag.

Labarbe, J. (1949) L'Homère de Platon. Paris: Les Belles Lettres.

Lampert, L. (2010) How Philosophy Became Socratic. A Study of Plato's Protagoras, Charmides and Republic. Chicago - London: The University of Chicago Press.

Liddel, H.G., Scott, R.A (1996) Greek-English Lexicon. 9th ed. New York / Oxford: Clarendon Press; Oxford Univ. Press.

Miralles, C. (2005) Homer. Barcelona: Empúries.

Morgan, K.A. (2004) "Plato", I.J.F. de Jong, R. Nünlist, A. Bowie, eds. Narrators, Narratees and Narratives in Ancient Greek Literature. Studies in Ancient Greek Literature. Vol. I. Leiden - Boston: Brill, 357-376. 
Morrison, J.S. (1941) "The place of Protagoras in Athenian Public Life (460415 BC)", The Classical Quarterly 35.1/2, 1-16.

Most, G.W. (1989) "The structure and function of Odysseus Apologoi", Transactions of the American Philological Association 119, 15-30.

Murray, P., ed. (1996) Plato on Poetry. Cambridge: Cambridge University Press.

Nagy, G. (1979) The Best of the Achaeans. Baltimore - London: John Hopkins University Press.

Nails, D. (2002) The people of Plato. A prosopography of Plato and other Socratics. Indianapolis: Hackett Publishing.

Nightingale, A.W. (1993) "The folly of praise: Plato's critique of encomiastic discourse in the Lysis and Symposium", Classical Quarterly 43, 112-130.

Parry, M. (1930) "Studies in the Epic Technique of Oral Verse-Making: I. Homer and Homeric Style", Harvard Studies in Classical Philology 41, 73-148.

Pascual, A. (2016) "Una estranya aparició. La qüestió inicial i l'inici de la qüestió socràtica al Protàgoras de Plató", Anuari de la Societat Catalana de Filosofia XXVII, 131-152.

Pfeiffer, R. (1968) History of Classical Scholarship: From the Beginnings to the End of the Hellenistic Age. New York - Oxford: Oxford University Press.

Planinc, Z. (2003) Plato through Homer. Poetry and Philosophy in the Cosmological Dialogues. Columbia - London: University of Missouri Press.

Planinc, Z. (2007) "Equivalences of Experience and Symbolization in Homer and Plato", Eric Voegelin Society, American Political Science Association, Chicago.

Proscurcin, P. (2018) "Some Thoughts on the Socratic Use of Iliad x 224 in Plato's Protagoras and Symposium: A Dialogical Context Previous to the Dialectic Method?", Maia: rivista di letterature classiche LXX.2, 240241.

Rademaker, A. (2013) "The most correct account: Protagoras on language", J.M. van Ophuijsen, M. van Raalte, P. Stork, eds. Protagoras of Abdera: the Man, his Measure. Leiden - Boston: Brill, 87-11.

Reale, G. (2001) Platone. Protagora. Milano: Bompiani.

Robb, K. (1994) Literacy and Paideia in Ancient Greece. New York - Oxford: Oxford University Press.

Rosen, S. (1968) On Plato’s Symposium. London: Yale University Press. 
Segal, C. (1994) Singers, Heroes and Gods in the Odyssey. Ithaca and London: Cornell University Press.

Segvic, H. (2006) “Homer in Plato's Protagoras”, Classical Philology 101, 247-262.

Strauss, L. (1965) Plato's Protagoras: A course by professor Leo Strauss. Chicago: Class audio transcript.

Tracy, S.V. (1997) "The structures of the Odyssey", I. Morris, B. Powell, eds. A New Companion to Homer. Leiden - New York - Köln: Brill, 360-379.

Velardi, R. (1989) Enthousiasmos: Possessione rituale e teoria della comunicazione poetica in Platone. Roma: Edizioni dell'Ateneo.

Verdenius, W.J. (1970) Homer, the educator of the Greeks. Amsterdam - London: North-Holland Publishing Company.

Wilamowitz-Moellendorf, H.U. (1920) Platon. I: Leben und Werke; II: Beilagen und Textkritik. Berlin: Weidmannsche Buchhandlung.

Woodruff, P. (2017) "Why Did Protagoras Use Poetry in Education?", O. Pettersson, V. Songe-Møller, eds. Plato's Protagoras: Essays on the Confrontation of Philosophy and Sophistry. Cham: Springer, 213-227. 